\title{
Subjetivações à Flor da Pele
}

\section{Subjectifications the flower of the skin}

\section{Resumo:}

Trata de pesquisa voltada para o estudo dos modos de vida contemporâneos, onde o cansaço se destaca como uma manifestação que vem se ampliando, chegando a se constituir como uma síndrome. As investigações em torno da Síndrome da Fadiga Crônica têm centram-se na busca por causas internas e individuais para o quadro. A categorização freqüente de novas síndromes nos indica ou um processo crescente e acirrado de adoecimento coletivo ou um processo crescente e acirrado de patologização do coletivo. Objetiva-se colocar em questão a fadiga como sinalizador dos modos de vida que se processam na atualidade, constituindo alertas desnaturalizadores de nossas formas de vida, muitas vezes, produtoras de adoecimentos. Individualizar a questão por meio da busca por uma precisão diagnóstica, capaz de definir o sentido do cansaço, bem como, sua localização física e/ou mental, parece contribuir mais para a manutenção e para a promoção de adoecimentos.

Palavras-chave: Subjetividade. Síndrome da fadiga crônica. Clínica. Tempo. Memória.

\section{Abstract:}

This research focuses on the study of contemporary lifestyles, where fatigue stands out as a demonstration that it has been increasingly coming to be constituted as a syndrome. Investigations around the chronic fatigue syndrome have focused on the search for individual and internal causes for the frame. A common categorization of new states or syndromes in a growing process and stern of illness or a collective process of growing and stern pathologizing the collective. It aims to call into question the fatigue as a marker of lifestyles that are processed in the news, providing alerts denatured our ways of life, often producing illnesses. Individualizing the question by looking for diagnostic accuracy, able to define the sense of fatigue, as well as its location physical or mental, seems to contribute more to maintaining and promoting the illnesses.

Keywords: Subjectivity. Chronic fatigue syndrome. Clinic. Time. Memory.
Machado, Leila Domingues. Subjetivações à Flor da Pele. Informática na Educação: teoria \& prática, Porto Alegre, v. 13, n. 2, p. 67-79, jul./dez. 2010.

\section{Leila Domingues Machado}

Universidade Federal do Espírito Santo

\section{Abertura}

A o longo da construção da trajetória de pesquisa que permeará a discussão desse artigo, o pensamento de Gilles Deleuze, seja em seus escritos solo ou ao desfrutar de inúmeras parcerias e da fecunda amizade com Félix Guattari, foi convocado a ressoar, por meio de um complexo labirinto conceitual, todo um campo analítico em torno das problemáticas que perpassam nossa atualidade. Há nos escritos destes autores uma generosidade compartilhada no esboçar de alguma idéia ou no desdobrar de uma questão. Está também aí a força de um movimento do pensar que se faz por contágio, por empréstimo de insight, por um convite à invenção conjunta de uma pop filosofia. Mas há ainda outro ponto, talvez mais discreto e espantosamente escandaloso, a intensidade das marcas produzidas pelas leituras e releituras de Espinosa. O pensamento já não pode mais estar no mesmo lugar. Os conceitos não possuem a mesma função. A pesquisa, a escrita, a docência são levadas para outros rumos. E tudo isso não se refere a novas leituras ou a uma aula magistral ou a certo domínio conceitual arduamente conquistado. Não se trata de erudição ou de oratória, muito menos de lógica ou da necessidade de sentido. As marcas de Espinosa roçam as sensações, dialogam com os perceptos, com os 
afectos, com uma inteligência que se espraia em meio ao não saber. Essa filosofia prática não poderá nunca ser recitada, muito menos ensinada. E isso não se dá porque ela pertença às idiossincrasias e sim porque ela sempre precisará ser experimentada por cada um, sempre precisará ser inventada e reinventada por meio do corpo e da alma daquele que deseja ser possuído pelos conceitos ao mesmo tempo em que os toma de assalto e faz junto a eles muitos filhos. Nesse caso, não se trata de querer ou de não querer dizer $e u$, pois esse eu já é toda gente, toda parte, que se faz numa intimidade sem precedentes consigo mesmo. A beleza do pensamento se mostra naquilo que ele move.

Em meio ao constante e incessante desafio da invenção de uma filosofia prática, compartilha-se aqui parte das inquietações que moveram uma pesquisa intitulada À Flor da Pele, realizada entre os anos de 1998 e 2001 junto ao Programa de Psicologia Clínica da PUC-SP, em parceria com Luiz Benedicto Lacerda Orlandi.

Nesse tempo um campo problemático se configurou, tendo como disparador o ecoar de falas que elegiam o cansaço como tema, como incômodo, como foco de atenção. As vozes que entoavam essa questão se compunham de muitas diferenças: idade, gênero, camadas social, profissão... Vinham das salas de aula, dos corredores, dos atendimentos no NPA (Núcleo de Psicologia Aplicada), das conversas com amigos...

O cansaço, ao qual se referiam, expressava, ao mesmo tempo, fadiga, descrenças, insuportabilidades, desajustes, sensações de não pertencimento, des-sintonias. Configurava-se uma espécie de queixa a partir de falas indicadoras de um incômodo. Contudo, parecia não se colocar uma preocupação no sentido da necessidade de um diagnóstico ou de tratar-se de uma situação patológica. Até porque havia uma dificuldade de definição do próprio cansaço como algo físico, psíquico ou ambos. Na maioria das falas o destaque era dado mais a uma idéia de cansaço existencial que se fazia sentir no corpo e na alma. As falas-queixa assumiam mais o sentido de compartilhamento de uma experiência, de um estranhamento com o que se passava, do que demonstrativas do desejo ou da demanda por uma classificação, por pertença a certo grupo. É claro que as experiências narradas eram referidas a algo individual, próprio e ín- timo aquele sujeito. Como as falas ecoavam, elas nos impulsionavam a pensar numa sensação grupal, ou melhor, numa experiência que apontava para um processo de produção que se fazia em sintonia com certos modos de vida em curso.

Embora toda uma sintomatologia faça parte da fala freqüente de muitas pessoas, o cansaço não vem sendo tratado como uma patologia no Brasil, diferentemente do que vem ocorrendo nos EUA. A chamada Síndrome da Fadiga Crônica é tida como uma patologia sem explicação precisa, no entanto, pode ser vista como expressão das configurações subjetivas que se engendram. A procura por causas internas e individuais para compor o conjunto explicativo dos quadros psicopatológicos que se proliferam a cada nova versão do DSM (Manual de Diagnósticos e Estatísticas das Perturbações Mentais), têm restringido e simplificado muito essa problemática. Por um lado, colocam-se cada vez mais os diagnósticos por co-morbidades, indicando certa flexibilidade classificatória, por outro lado, a categorização freqüente de novas síndromes nos indica ou um processo crescente e acirrado de adoecimento coletivo ou um processo crescente e acirrado de patologização do coletivo. Poderíamos pensar as síndromes mais como conjunto de sinais do que como conjunto de sintomas. Ou seja, mais do que a constatação de um quadro patológico, mostra-se fundamental estar atento para os indícios que emergem no entrelaçamento configurações subjetivas e pontos de aplicação de estratégias e táticas operadas pelo capital no contemporâneo. Sinais que podem ser concebidos como indicadores, tanto do cansaço quanto de sua reversão.

Nossa intenção neste artigo é colocar em questão a fadiga como sinalizador dos modos de vida que se processam na atualidade. Nesse sentido, considera-se que a discussão psicopatológica precisa estar muito mais imbuída de uma preocupação ética do que de julgamentos morais, de necessidades diagnósticas, de precisões etiológicas, de crença em fármacos milagrosos e solucionadores per si. Também não consideramos tratar-se de indivíduos isoladamente adoecidos.

A temática do cansaço convoca o desdobrar de questões que tencionem todo um campo problemático, embaralhando luz e sombra, silêncios, sussurros e gritos. Iniciaremos apre- 
sentando a concepção que criamos na tentativa de dar passagem aos jogos de força que perpassam o cansaço. Denominamos à flor da pele aos processos que movem essas configurações subjetivas ou como, em parceria com Luis Orlandi, nomeamos nebulosa, como confluências de passagem, como expressos de multiplicidades que roçam marcas repletas de afeto na areia. Pois as subjetivações à flor da pele encontram-se num limiar, num entreformas onde certa configuração subjetiva se desfez sem que outra tenha surgido.

Num segundo momento, elegemos o cinema como intercessor para que, por meio de suas imagens transformadas em palavras, possamos percorrer as visibilidades e as dizibilidades do cansaço, das subjetivações à flor da pele, encarnado no corpo e na alma de uma personagem, Nikos, no filme Entre o Inferno e o Profundo Mar Azul (1995). Acompanhar os sutis movimentos de Nikos, sua luta silenciosa, seu grito contido, seu torpor, sua mão cortada, sangrando, sua mão estendida para a vida que Ihe roça em meio às feições de Li, cada um desses breves lampejos de luz sobre a tela branca, configuram-se como sinais da nebulosa subjetivações à flor da pele. Os sutis movimentos de Nikos misturam o torpor do seu corpo ao dilaceramento da sua alma, experiência de um entre-formas que também sede lugar, permite a passagens, corpo e alma percorridos por sopros de vida, como nos fala Clarice Lispector (1978).

\section{Subjetivações à Flor da Pele}

À flor da pele. Subjetivações à flor da pele. Subjetivações no limiar. Certa configuração subjetiva se desfez e não há ainda outra. Tudo estremeceu. Nada permanece no lugar. As certezas ruíram e todo um campo problemático emergiu. Nesse entre-formas, nesse intervalo entre o antes e o depois que os envolve, tudo é claro e nebuloso e irremediavelmente diferente. Sempre mais e menos, ao mesmo tempo, mas nunca igual. Um dinamismo espaço-temporal de espera e esforço. Uma vertigem, um desassossego, que faz a pele porosa e permeável.

E eles "[...] não tentaram nada de especial que estivesse acima de suas forças; no entanto, despertam como se saíssem de uma bata-
Iha grande demais para eles, o corpo quebrado, os músculos pisados, a alma morta [...]" (DELEUZE, 1974, p. 157).

No entanto, não se trata de nenhum tipo de morte empírica e sim da marca discreta da morte que os convoca a afirmar a vida como potência de criação, como potência de possíveis. A vida jorra por entre as grades que procuram sempre capturá-la e nos força a um estranho atletismo, pois algo aconteceu que nos deixou "[...] com os olhos vermelhos e o fôlego curto [...]" (DELEUZE; GUATTARI, 1972, p. 224) e, ao mesmo tempo, nos invadiu de uma força que faz viver.

E o que aconteceu? Nada de demasiadamente grande ou pequeno e que fez toda diferença. Nada que antes estava oculto e agora se mostrou. Nada de especial, antes algo que faz parte do cotidiano ${ }^{1}$ e sempre esteve ali: "[...] a luta da vida com aquilo que a ameaça [...]" (DELEUZE; GUATTARI, 1972, p. 222).

Só que naquele instante, todos os esquemas sensório-motores que nos protegem, que impermeabilizam nossa pele, que nos fazem suportar, se bloquearam ou se quebraram e nos tornamos videntes ${ }^{2}$ naquele instante.

E o que vemos não é o futuro e sim o que transborda no presente. "O vidente vê o possível e, com isso ascende a uma nova possibilidade de vida que pede para se realizar [...]" (ZOURABICHVILI, 2000, p. 341) e nos incita a cria-la. Ele cheira a poeira das virtualidades, roça o Fora e experimenta o sabor da potência para inventar a vida.

A vidência é um acontecimento que nos faz ver a multiplicidade de forças que percorrem uma situação, o duplo de tudo e de cada coisa, suas linhas de segmentaridade mais duras ou mais flexíveis, mais sedentárias ou mais nômades, e suas linhas de fuga, de fissura, de

\footnotetext{
10 cotidiano envolve os conflitos presentes em uma época. "Determina assim o lugar em que se formulam os problemas concretos da produção em sentido amplo: a maneira como é produzida a existência social dos seres humanos $[\ldots . .]^{\prime \prime}$. Isto porque, a "[...] produção não se reduz à fabricação de produtos $[\ldots]$ ", pois também é fabricação de gente, é "[...] produção do 'ser humano' por si mesmo [...]" e por isso implica "[...] uma ética subjacente ao emprego do tempo, uma estética da decoração desse tempo empregado [...]" (LEFEBVRE, 1991, p. 30-37).

2 "[...] se nossos esquemas sensório-motores se bloqueiam ou se quebram, então pode aparecer outro tipo de imagem: uma imagem óptico-sonora pura, a imagem inteira e sem metáfora, que faz surgir a coisa em si mesma, literalmente, em seu excesso de horror ou de beleza, em seu caráter radical ou injustificável, pois ela não tem mais de ser 'justificada', como bem ou como mal [...]" (DELEUZE, 1990, p. 31).
} 
resistência. Assim, o vidente também vê tudo o que se mostra intolerável. Vê

[...] aquilo que captura nossa potência de exploração dos possíveis, fazendo dela um ponto de aplicação de estratégias e táticas operadas pelo capital, desde suas esferas produtivas até sua exacerbação financeira, de orquestração midiática de opiniões e procedimentos artísticos, e de alinhamento mercantil dos desejos [...] (ORLANDI, 2000)

O acontecimento instaura uma fissura, abre-se uma rachadura em nós que promove uma mutação subjetiva, que leva "[...] a uma nova distribuição entre o bom e o mau, o deleitável e o insuportável, ora em uma mesma pessoa (que, a partir de então, mal pode identificar o passado que viveu como seu passado), ora em uma coletividade [...]" (ZOURABICHVILI, 2000, p. 338-339).

$\mathrm{E}$, assim, em um primeiro tempo, experimentamos o antes como sendo grande demais para mim e, assim, qualquer ação parece grande demais para qualquer um. Contudo, o próprio presente já é de metamorfose, já se está em um segundo tempo, já se está em um limiar. Em um terceiro tempo, podemos perceber que

[...] o acontecimento e a ação tem uma coerência secreta que exclui a do eu, voltando-se contra o eu que se Ihe tornou igual, projetando-o em mil pedaços, como se o gerador do novo mundo fosse arrebatado e dissipado pelo fragmento daquilo que ele fez nascer no múltiplo: aquilo a que o eu é igualado é o desigual em si [...] (DELEUZE, 1988 , p. 157).

Frente a essa turbulência abrem-se ilimitadas possibilidades, que podemos acolher e recusar. É como se nesse limiar funcionasse uma espécie de pêndulo que envolve modulações entre potência e impotência ${ }^{3}$. Pois se

\footnotetext{
3 Para Espinosa todos nós somos graus de potência [potência de pensar e potência de existir], entendendo por potência nossa capacidade de ser afetado, que é preenchida por afecções [imaginações] e por afectos [paixões]. Experimentamos uma incessante luta de potências. Somos afetados por paixões tristes, que paralisam, diminuem, impedem, nos separam de nossa potência de agir. "A paixão triste é sempre de impotência". E também somos afetados por paixões alegres que nos impelem à ação. Na tristeza, toda a potência está circunscrita à dor e quer destruir outras potências como objetos causadores do sofrimento. Na alegria, a potência está em expansão e quer compor com outras potências. Por isso, a alegria aumenta nossa potência de agir enquanto a tristeza a diminui e a impede. Para tratar os conceitos propostos por Espinosa, teremos como referência: Deleuze, ([19-- $], 1997 a)$
}

pode acolher o desassossego ou recusa-lo, ora se acredita e ora se é invadido pelo medo, ora tristes e descrentes estamos em fadiga e ora alegres e potentes estamos em esgotamento (DELEUZE, 1992b).

O fatigado não pode mais realizar, pois ele esgotou toda a realização. Todavia, a realização não esgota o possível. Ele se cansa de realizar, não há mais nada a ser realizado. Ele apóia o devir no nada e tem medo do devir. Ele está tomado por uma vontade de nada. Ao contrário, o esgotado não pode mais possibilitar, pois ele esgotou todo o possível. Ele apóia o devir na potência e a expande ao máximo. Ele está tomado por um nada de vontade.

Diante de um acontecimento, realizar uma possibilidade é um ato de aderência, é reduzir o acontecimento a um sentido existente o jogando no plano do Mesmo, do Semelhante, do Idêntico, dos objetivos, dos projetos, das preferências, das finalidades que se processam por disjunções exclusivas. Diante do acontecimento, efetuar o possível é criar, em imanência com o acontecimento, agenciamentos que lhe dêem consistência, afirmando outra sensibilidade, enfim, outras possibilidades de vida que se forjam junto ao próprio desejo de mutação em disjunções inclusivas (DELEUZE, 1992b).

O nada de vontade é uma força desintegradora que coincide um mínimo e um máximo de vida, que resgatam as situações como potência de encontros com o mundo. Vontade de nada seria um déficit de vontade, certa má vontade. Perdemos o gosto porque acreditamos que nada é possível e, assim, somos invadidos por uma fadiga, por um tédio.

Quando se está em fadiga, procura-se sustentar a ilusão de estabilidade promovendo, apenas, rearranjos nas possibilidades. Com isso, nega-se a condição de vivo, construindo uma forma-homem que não comporta as dimensões do inumano. Uma sobrevida que se restringe ao visível, às percepções, aos sentimentos, à razão, à inteligência 4 . A multiplicidade da vida não encontra passagem para ressoar em uma sobrevida. A turbulência e suas vibrações são amortecidas e cessadas pela anestesia que impermeabiliza a pele. As

\footnotetext{
4 Essa discussão é amplamente desenvolvida por Suely Rolnik em vários de seus trabalhos. Nesse ponto, nos reportamos mais especificamente ao curso baseado no livro de Deleuze Lógica das Sensações: Francis Bacon, oferecido no Programa de Estudos Pós-Graduados em Psicologia Clínica da PUC-SP, no ano de 2001.
} 
forças intensivas são capturadas ou circunscritas pelos modelos, em lugar de os estremecerem.

É nesse sentido que a vida se torna enclausurada. A expansão da vida, a potência de diferenciação, que nos permite criar outras formas de existência, é capturada por formas padronizadas de ser e de estar. Por isso, essa forma de individuação pode ser tanto individualista como antiindividualista. De um jeito ou de outro, o que está em funcionamento são modelos. $E$ o que acontece é que modelos não criam, não inventam outras soluções, não mudam de estratégia quando é necessário. Os modelos não nos fazem pensar e sim aderir.

Um acontecimento implica conexões de forças que afetam a criação de formas que lhe dêem passagem. Um acontecimento promove mudanças no dinamismo espaço-temporal, abrindo outras possibilidades de vida, outros "[...] modos de se estar nos verbos da vida [...]" (ORLANDI, 2002, p. 237). Enfim, criação de agenciamentos concretos que seriam o expresso do próprio acontecimento. Mas esse expresso não é da ordem da significação e sim do sentido, isto é, da avaliação, da confrontação de valores e da própria afirmação da possibilidade de vida como critério de avaliação. Uma redistribuição dos afectos, potência de diferenciação abrindo possíveis. Transmutações que fazem a vida se expandir.

À flor da pele. Subjetivações à flor da pele. Subjetivações no limiar. Barcos sem porto, sem rumo, sem vela. Bichos soltos, cães sem donos, cavalos sem celas (BALEIRO, 199-), que não sabem para onde ir ou o que fazer. Toda a pele percorrida por sensações de apreensão e incerteza. Padecemos a dimensão do acontecimento e estamos esfacelados.

Os ventos sopram de todos os lados, mas o ar está saturado e o oxigênio rarefeito. É preciso forjar portos, bóias, ancoradouros, mas no sentido da criação de planos de consistência, de territórios existenciais que se engendram na experimentação do mundo. O homem precisa acreditar no liame com o mundo, na ligação com o mundo, nas conexões com a vida (DELEUZE, 1990, p. 207-209), pois o homem tem sido desapossado do mundo.

Entretanto, acreditar no liame com o mundo difere inteiramente de aceitar o mundo, de subjugar ou de ser subjugado por ele. Tratase de tomar posse do mundo, ou melhor, de inventar mundos. O que implica avaliações e escolhas ético-estético-políticas pela potência e não pelo poder. A invenção de mundos é o caminho que nos leva a fugir do império do intolerável ou de tudo aquilo que tem nos desapossado do mundo.

Quando não inventamos mundos corremos o risco de um mundo ideal vir recobrir o que parece sem sentido, oferecendo esquemas sensório-motores para aliviar a dor. O barco sem rumo, sem porto, sem vela permanece ao sabor das ondas quando não se acredita capaz de criar para si cartas de navegação, ou meIhor, cartografias traçadas em imanência com o contemporâneo.

No entanto, estar à flor da pele pode impulsionar aberturas, como uma artéria que se rompe. O sofrimento pode forçar o pensamento a pensar o impensável, a criar sentidos para a dor. Não em um apaziguamento ou em uma tolerância ou em um suportar a dor e sim em sua transmutação em alegria ${ }^{5}$ Interstício das palavras, das imagens, do amor, do pensamento, da memória, do 'eu'. Interioridade atraída para fora de si em proveito de hecceidades (DELEUZE; GUATTARI, 1972, p. 222) ou de modos de individuação que não procedem pela forma e nem pelo sujeito e sim nos acontecimentos, nas intensidades.

[...] é sentir de repente crescer em si mesmo um deserto, no outro extremo do qual (embora esta distância sem medida é tão fina como uma linha) espelha uma linguagem sem sujeito atribuível, uma lei sem deus, um pronome pessoal sem pessoa, um rosto sem expressão e sem olhos, um outro que é ele mesmo [...] (FOUCAULT, 1990, p. 62).

\section{3 É Cedo Demais... É Tarde Demais...}

A partir desse ponto, tendo o cinema como intercessor no percurso desse campo problemático, Nikos, personagem do filme Entre o Inferno e o Profundo Mar Azul (1995), nos emprestará seus olhos, sua pele, sua dor e suas alegrias para que possamos junto aos sussurros da vida que o perpassam, bem como,

5 Uma alegria ética correlata de afirmações especulativas e que se difere dos deveres morais. Um esforço de avaliações e escolhas, em imanência com o que vivemos, das forças com as quais iremos compor. Experimentação da alegria, da potência de agir, da expansão do poder de ser afetado, da transmutação das tristezas que nos percorrem e, também, da posse dessa potência de agir que nos faz suscitar acontecimentos. (DELEUZE, [19--]) 
junto aos sussurros de tantas vidas anônimas que transitam pelas ruas da cidade, experimentar as vibrações dos jogos de forças que se fazem nesse tempo de espera, nesse dinamismo espaço-tempo de passagens que se fazem à flor da pele.

A cidade ${ }^{6}$ está ao longe, distante e presente. Uma névoa percorre o mar e a cidade e nos permite apenas ver os contornos meio disformes de seus edifícios. Não há ninguém nessa imagem, somente a cidade ao fundo e os barcos balançando ao mar. O porto e a cidade permanecem distantes em meio à névoa. Um navio vem chegando e lança âncora. Dentro dele está Nikos, um marinheiro fatigado que responde ao mundo: Não sei, Talvez. Não sabemos por onde andou, para onde vai e nem quando. Era uma vez um mandarim solitário, triste e perdido... Era uma vez um marujo solitário, triste e perdido....

Os outros marinheiros jogam cartas, conversam, conhecem pessoas, vão à cidade. Nikos permanece deitado. Ele parece querer não querer nada. Está por demais cansado para querer. Ele se mantém em uma existência opaca, não joga, não vai à cidade, não conversa, não quer conhecer ninguém. Em sua cabine, prepara o cachimbo de ópio que irá Ihe confortar, que irá suavizar a dor, que irá anestesiar sua existência.

Deitado, uma mão na cabeça outra no peito, acariciando a imagem de uma mulher encravada em sua pele. A voz dela nos chega: Olhei no dicionário... eu te amo em grego é s'agapô, espero por você, a gata deu cria hoje..., quando você voltar..., o porão já encheu.... Um profundo tédio o domina. Uma profunda tristeza percorre o seu olhar. Um profundo cansaço paralisa seus passos. Uma terrível indigestão cala suas palavras e faz doer o contato. Ao mesmo tempo, há uma intensidade de sensações percorrendo sua pele.

Ele não conversa e não está em silêncio, ou melhor, ele pouco fala e pouco escuta e não há silêncio e sim uma profusão de ruídos, de palavras. Ele fecha os olhos e não vislumbra um vazio e sim uma profusão de imagens que não vemos. O dizível se coagulou no que foi dito. O visível se coagulou no que foi visto. As palavras compõem ladainhas que ecoam sem

6 Essa seção gira em torno da película: Entre o Inferno e o Profundo Mar Azul (1995). cessar. O que foi dito cessa novos dizeres, recobre possíveis sons com o barulho ensurdecedor de seu eco. É impossível estar sossegado. É impossível ver os sons do silêncio. É impossível ouvir os vazios das imagens.

Há uma mulher que não vemos, só ouvimos sua voz em off. As palavras não cessam, são indigestas, consomem os pensamentos de Nikos. Sua imagem não se apaga, é um rosto tatuado em seu peito. O seu corpo está imerso em uma forma de memória7, em Mnemósina. Ele acredita não haver passagem para o que acontece porque o que lhe aconteceu preenche todo o seu corpo e ocupa todos os sentidos. Nikos sucumbe ao passado por não conseguir se apoderar do passado. Seu presente torna-se passado, seu futuro torna-se passado, e o passado Ihe escapa, como também Ihe escapa o presente e o futuro. Tudo é um Mesmo, tudo é igual, tudo passou.

A voz em off preenche seu cotidiano e toma posse de sua vida. O passado assume a forma de um presente que passou e está irremediavelmente perdido. O tempo se endureceu em um presente infinito que contrai o passado e o futuro e os limita a sucessão dos instantes que passam ${ }^{8}$. Um tempo coagulado no hábito e na memória, no ópio e nas palavras que ecoam sem nunca dizerem outra coisa.

Ele está cansado de lembrar e experimenta uma paralisia, uma impotência. Em um presente que se estende ao mesmo tempo em direção ao passado e ao futuro, Nikos aprisiona seu presente entre um passado perdido e um futuro sem saída. Um inferno de lembranças toma posse de seus dias e de suas noites. Palavras saturam seus ouvidos e seus olhos e há pouco espaço para outras paisagens, para

\footnotetext{
7 A memória assumiria aqui o sentido de memória voluntária, tal como é exposta por Deleuze a partir da obra de Proust. Nessa forma de memória, o presente atual vem em direção a um presente que foi por acreditar que os segredos das lembranças encontram-se nessa sucessão de presentes. Nesse sentido, a memória voluntária recompõe o passado com o presente sem se apoderar dele, pois lhe escapa o ser em si do passado. (DELEUZE, 1987).

8 Deleuze, a partir de Bergson, apresenta alguns paradoxos para pensarmos o passado: 1) o passado é contemporâneo do presente que ele foi, ou seja, o passado se constitui ao mesmo tempo em que é presente; 2) o passado coexiste com o presente, ou melhor, com presentes que ele não foi e em relação ao quais ele sempre foi passado; 3 ) o elemento puro do passado preexistiria a todo presente, ou seja, há um passado que jamais foi presente, que nunca se atualizou, um passado puro que é nuvem virtual do presente; 4) o presente seria a ponta mais contraída de todo o passado, ao mesmo tempo em que, todos os passados coexistem entre si em diversos graus de contração e de distensão. (DELEUZE, 1988)
} 
outras palavras. Só há cartas, cartas vindas de não se sabe onde, que lhe pedem notícias, que lhe perguntam por onde esteve, onde está e para onde vai. Ele sabe de cor cada palavra e elas vagam por sua vida, delineiam seu tempo, instalam-se em seu olhar, são recitadas por seus lábios.

Tudo o que parece distante está ali e ele não suporta mais. Tudo o que passou está ali e ele já não suporta mais. Você não pode me esquecer. Estou em você, inapagável em seu coração. Essa memória é intolerável. Ele afaga um gato, um suave ponto de conexão com a vida, e seus dedos deslizam por entre os pelos amarelos que se confundem com os fios loiros do cabelo de uma mulher. Eu te amo em grego é s'agapô. No país onde está como se diz eu te amo?. Por que não me escreve?. Olho o mapa e não sei....

Ele permanece no mar porque a terra o assombra. Vem de lá sua memória, seu medo. Minha cama está cada vez maior. Durmo na beira para guardar seu lugar. Estou com frio. Parece que o inverno nunca acaba... Onde você está?. E ele não sai do barco, não quer sair do barco, não consegue sair do barco. Devia experimentar, mas não consegue. O profundo mar azul é acalanto, refúgio movediço, e inferno das ondas da memória. O continente está distante, enevoado, nenhum cais ali se vislumbra e isso é assustador.

A companhia em que trabalha faliu. O navio será vendido ou confiscado em cinco dias. Temos de esperar, ele diz. O que esperar? Como será feita essa espera? O tempo de espera se converterá em um grito de dor? Manter a espera será travestir a dor em alívio nos cachimbos de ópio?

O capitão do navio esbraveja perante a situação de falência e bebe, bebe demais. Mas a embriaguez não incomoda Nikos e sim a lucidez, a excessiva lucidez, então ele fuma demais. Viagens de ópio. Viagens em um mar de gelo. Um frio imenso que não consegue se aquecer. Um corpo despedaçado, esfacelado, esvaziado. Órgãos sem corpo. Nikos sofre ao não conseguir dar corpo à experimentação, ao não conseguir transmutar a dor em alegria. Seria preciso não fazer de si um coágulo, se dissolver e, ao mesmo tempo, "[...] ter sempre um pequeno pedaço de uma nova terra [...]" (DELEUZE; GUATTARI, 1972, p. 24).

Os outros marujos tentam fazer contatos para definir o próximo trabalho, o próximo porto, as próximas cidades, as águas por onde irão passar. Nikos quer permanecer imóvel naquele barco. Não quer ir ao porto, não quer ir à cidade, não quer fazer contatos, não quer falar com ninguém, não quer ouvir nada de ninguém. Quer permanecer deitado com a barba por fazer. Não quer querer. Ele tem medo das pessoas, da cidade, da miséria, da vida. Tudo isso dói por demais e ele não suporta essa dor. Ele quer esperar.

\section{Tempo de Espera}

Tudo o que acontece o desestabiliza e o faz mergulhar em recordações. E uma nova imagem não se faz. E um novo som não se faz. Ele está entre antes e depois, está à flor da pele. A um só tempo anestesiado e excessivamente poroso. Que fazer nesse interstício temporal, nesse intervalo onde o antes se mostra intolerável e o depois se mostra imprevisível? Ele se preenche de medo e procura se ancorar em um presente que só se faz do antes ou de um passado perdido que insiste em não passar. No entanto, ele não parece estar à espera disto ou daquilo, desta ou daquela rota, mas de que algo não premeditado venha a devir, à espera de que um acontecimento Ihe subtraia do cais de Mnemósina, de uma memória do Mesmo.

O sofrimento de Nikos é um abismo do presente. Ele experimenta o tempo como se fosse um presente sem fim, uma perpetuidade instável e destituída de futuro. Um tempo onde o próprio presente escapa. Um tempo parado e incapaz de permanência, onde "[...] aquele que sofre está privado, justamente pelo sofrimento, deste 'Eu' que o levaria a sofrer [...]" (BLANCHOT, 2001, p. 89).

Ele vive um estranhamento, um desassossego, não é mais o mesmo e ainda não é outro. Todas as coisas presentes permanecem suspensas, pois esse presente é a exterioridade mesma da presença, ou melhor, é a presença não-presença da alteridade. Por isso, ele se defronta, ao mesmo tempo, com toda a impossibilidade de uma forma de vida e com toda a potência de possibilitar outra vida. Sua espera é expectativa sem presente e preparação da vinda do que sempre vem, de um devir. A experiência de Nikos envolve um 
tempo da espera ${ }^{9}$. Certa relação com o tempo acompanhada da decepção (DELEUZE, 1987, p. 34-37).

Tempo das subjetivações à flor da pele. A companhia faliu, o amor faliu, a vida faliu, só resta esperar. O mar mostra-se intolerável, o amor mostra-se intolerável, a vida mostra-se intolerável, só resta esperar. É como se não houvesse mais nada a fazer e tudo a ser feito. Grau máximo de saturação e grau zero de potência entre um antes e um depois.

O tempo da espera é feito de batalhas. Multiplicidades envolvem cada combate. Gradações se fazem entre o vazio transparente da espera e a saturação opaca da espera. É tarde demais... ou cedo demais.... Já é tarde e cedo ainda. Entre o antes e o depois, o entardecer e o amanhecer se encontram, o dia se mistura com a noite. Tudo é claro e nebuloso. Um limiar tênue separa potência e impotência em vias de serem inventadas. "Conservar os músculos descontraídos e a vontade desembaraçada, é o que é mais difícil para vós [...]" (NIETZSCHE, 1985, p. 131).

Um tempo tenso, enrijecido, contraído e, também, prestes a se esgarçar, a se quebrar, a se distender. Um tempo entre a memória e o esquecimento. Entre um tempo perdido e um tempo redescoberto. Um tempo próprio da espera, o atraso e o prazo para a alegria e para a dor. Esperar ilimitadamente a alegria, a potência, a vida, esperando finitamente a dor, a náusea, o medo, o tédio, a tristeza, a impotência, a descrença ${ }^{10}$.

O tempo da espera é povoado por uma multiplicidade de forças, por diferentes fluxos, por incessantes combates entre linhas de poder e linhas de resistência. Com quais forças Nikos irá compor? Pois a espera pode se desdobrar em invenção de possíveis e em perpetuação da impotência. Ele pode desejar

\footnotetext{
9 Tomamos emprestada uma afirmação de Deleuze, acerca da espera na experiência masoquista, para pensarmos o tempo de espera nas subjetivações à flor da pele. Essa idéia nos interessa em função da espera se desdobrar em fluxos e se vincular a uma forma tempo que a torna possível. A respeito da espera no masoquismo, confira Deleuze (1983).

10 o tempo perdido seria uma linha do tempo aprisionada ao eu. É um tempo de sofrimento, pois nada nos revela o segredo que esperávamos. Diante dessa decepção, procuramos o sentido da dor nas particularidades do eu. Entretanto, nos escapa que o sentido seja múltiplo, aproximativo e esquivo, se configurando somente quando os eus se dissolvem em proveito de individuações sem sujeito. Mas, esse sofrimento também pode forçar o pensamento a pensar, a criar sentidos, a se fazer nesse apagamento do eu, em um tempo redescoberto. (DELEUZE, 1987)
}

o esgotamento ou ser capturado pela fadiga. É o "[...] espírito transformado em besta de carga [que] toma sobre si todos estes pesados fardos $[. .$.$] ", pois "[...] a sua força reclama far-$ dos pesados, os mais pesados que existam no mundo [...]" (NIETZSCHE, 1985, p. 29-30).

Mas, para que a espera de Nikos se desdobre em potência, ele não pode se agarrar à esperança para aplacar o medo. Pois a esperança ${ }^{11}$, quando vinculada à espera do provável ou à ficção do irreal, torna-se uma paixão triste, uma potência de padecer ${ }^{12}$. O tempo da espera então se enclausura no sofrimento, na indignação, na vontade de nada, no ressentimento, e se preenche de um passado perdido e de um futuro sem saída. Mas, o tempo da espera pode se desdobrar em alegria ativa ${ }^{13}$, em potência de agir, se o esperar se despoja de toda esperança manifesta (BLANCHOT, 2001, p. 84) e se vincula à criação de possíveis em imanência com a vida. O tempo da espera se abre a outros tempos, os venenos se expõem a seus antídotos, a indigestão se abre à digestão, a memória se expõe ao esquecimento.

É no esquecimento que a espera se mantém como uma espera: atenção aguda àquilo que seria radicalmente novo, sem ponto de comparação nem de continuidade com nada (novidade da espera exterior a si e livre de todo o passado) e atenção àquele que seria o mais profundamente velho (posto que nas profundidades de si mesma a espera não deixou nunca de esperar) (FOUCAULT, 1990, p. 73).

No convés Nikos permanece olhando ao lon-

11 "A esperança não é senão uma alegria instável, nascida da imagem de uma coisa futura ou passada, de cujo resultado duvidamos [...] As afecções de esperança e de medo não existem sem a tristeza. Com efeito, o medo é uma tristeza, e a esperança não existe sem o medo" (ESPINOSA, 1992, p. 404-405).

$12 \mathrm{Na}$ tristeza toda a nossa potência está voltada para o padecimento. "Nossa potência está imobilizada e não podemos senão reagir [...]" (DELEUZE, [19--], p. 121). Decompomos nossas forças, diminuímos nossa potência de agir e fazemos do padecimento uma cantilena de reclamações, de acusações, de recusas, de culpabilizações, de ressentimentos. (DELEUZE, 1997a).

13 A alegria ativa, para Espinosa, vem de uma paixão alegre que aumenta nossa potência de agir, que amplia nossa capacidade de ser afectado. Entendendo essa ampliação como uma mudança na qualidade das forças, ou melhor, como um esforço para criar 'bons encontros' ou encontros que nos façam viver. No entanto, a alegria ativa se dá quando saímos do domínio das paixões e tomamos posse da alegria e da potência de agir, quando nos tornamos dignos da ação, quando escolhemos a escolha, quando afirmamos a afirmação, quando há em nós um esforço de criação do que nos faz viver. (DELEUZE, [19--], 1997a) 
ge. Seu olhar é triste, seu corpo é triste, seus movimentos são tristes. Em outros momentos, ele está deitado, o olhar perdido, vagando inerte ou cerrado em um sono acordado. Ele não dorme, não sonha, não consegue descansar. Vive no mar, nas ondas revoltas do mar. Em sua vida a terra é escassa. Os contornos se desfazem em meio à névoa. Ele percorreu muitos mares e forjou pouca terra, esse meio vital lamacento onde nascemos e morremos. "E embora haja na terra atoleiros e muita e espessa tristeza, quando se têm os pés leves, atravessa-se a correr o próprio lodo, e dançase como por cima do gelo liso [...]" (NIETZSCHE, 1985, p. 330).

A terra como matéria-prima a ser amassada, misturada, moldada. Onde formas são criadas e desfeitas, onde portos são erguidos para atracar os barcos e de onde estes partem para o mar. Terra como densidade intensiva, como corpo de gradações entre o sólido, o líquido e o gasoso, onde esses se misturam, se sobrepõe, se intercalam em contrações e distensões. Terra como morada, como um si feito de individuações sem sujeito, de subjetivações não capturadas pelo Idêntico, pelo eu. A terra como tempo e o tempo como terra ${ }^{14}$, dos que vem da terra, dos que sabem a terra, dos que aprendem a inventar a leveza dos pés a tocar seu solo.

Nikos é um marinheiro sem pátria, um alóctone, seus pés tocam pesadamente a terra, ele não vislumbra contornos, não consegue criar contornos, não consegue dar formas a esse meio vital lamacento. E, assim, ele toma emprestadas formas saturadas que repelem o contato e tentam ainda conservar o 'eu' que Ihes resta nas palavras gastas e na solidão.

Do navio, Nikos olha de longe o porto, escuta os sons da cidade no mar. É um prisioneiro repleto de medo a contemplar o mar, a terra e suas cidades. O que ele não percebe é que é inútil dizer que o mar ou a terra nos faz feliz ou infeliz ou "[...] dividir as cidades nessas duas categorias, mas em outras duas: aquelas que continuam ao longo dos anos e das mutações a dar forma aos desejos e aque-

14 "A terra como tempo primordial dos autóctones $[\ldots]$ ", onde todos "[...] os estratos coexistentes se comunicam e se justapõem no meio vital lamacento [...]" (DELEUZE, 1990 , p. 141). A terra como matéria-prima. O tempo como terra, como "[...] massa a ser incessantemente moldada, ou modulada, estirada, amassada, comprimida, fluidificada, densificada, sobreposta, dividida, distendida etc." (PELBART, 1998, p. 19-20). las em que os desejos conseguem cancelar a cidade ou são por esta cancelados [...]" (CALVINO, 1999, p. 36-37).

Não se trata, tampouco, de escolher entre o mar e a terra. Não adianta Nikos ir para a terra e ficar olhando de longe o mar. Por outro lado, a questão não é apagar as diferenças entre terra e mar ou fazer deles uma unidade ou fazer de si junto a eles uma unidade. Ele precisa aprender a criar combinatórias entre o mar e a terra. Aprender a combinar o conjunto das variáveis de uma situação promovendo disjunções inclusivas (DELEUZE, 1992b, p. 38). O que difere de aguçar suas preferências, de cumprir seus objetivos ou de realizar seus projetos.

Toda essa memória encravada de pessoalidade fatiga Nikos. O faz ouvir sempre as mesmas palavras ecoando e estar por demais cansado para dizer qualquer coisa. Ele parece condenado a preferir ou a não ter escolhas: ou lembra ou vive, ou está no mar ou está na terra. Mas, não se trata de escolher entre ir à cidade ou permanecer no navio, viver ou lembrar. Essas disjunções exclusivas abafam possíveis. Nikos precisa inventar a escolha. Que outra memória é possível? Que outra vida é possível? E se as palavras estão saturadas, é preciso arrancar-lhes as aderências, os clichês (DELEUZE; GUATTARI, 1972, p. 274) que as recobrem, toda pessoalidade que as enclausura e faze-las dizer outra coisa. Não permanecer cansado de lembrar e sim esgotar todo o possível da memória, inventar possíveis junto à memória, junto ao mar, junto a terra.

O mar pode sacudir a areia, promover misturas, fazer, desfazer e refazer seus desenhos. E a areia pode oferecer terra firme para o quebrar das ondas. Um marujo deseja o mar, deseja navegar por seus mistérios. Um marujo também deseja a terra, deseja um cais provisório onde seu corpo possa parar de balançar. Há terra no mar e água na terra. Talvez seja necessário promover interstícios entre o mar e a terra. Cavar a terra para fazer a água jorrar. Mergulhar no mar e tocar a terra.

Nikos não consegue criar essa composição ${ }^{15}$. Tudo o que vê são névoas. É um bar-

15 "A irrupção de um acontecimento nos convoca a criar figuras que venham dar corpo e sentido à arregimentação de diferenças que ele promove. Faz tremer nossos contornos e nos separa de nós mesmos, em proveito do outro que estamos em vias de nos tornar. Perdem sentido as nossas cartografias, depaupera-se a nossa consistência, nos fragilizamos - tudo isso ao mesmo tempo [...]" (ROLNIK, 1995, p. 97). 
queiro sem rota, sem leme, sem âncora, que se esparrama em seu sofrimento e teme esquecer a si mesmo, se perder nessa dor, desfigurar-se. O medo de se esquecer é o medo de não conseguir criar planos de consistência que acolham o que acabou de acontecer e o que vai acontecer. $\mathrm{O}$ medo de se esquecer é o medo de esquecer a memória que o corrói, que o dilacera, que se tornou o centro de sua vida e o santuário de sua cotidiana mortificação. Uma memória transformada em veneno que intoxica e que não se digere. "[...] o homem conseguiu esta fraqueza do estômago e esta linguagem mentirosa, que Ihe tornam insípida e dolorosa a vida: de modo que, algumas vezes, inclina-se sobre si mesmo, tapando o nariz [...]" (NIETZSCHE, 1992, p. 55).

A náusea coagulou sua vida, cortou o fluxo sanguíneo, estancou a alegria, interrompeu um processo. E essa parada no processo parece lhe impedir a criação de sentidos para a vida. O processo se ligou a um fim, a uma finalidade, e é conduzido ao infinito (DELEUZE; GUATTARI, 1972, p. 9-10). Então, Nikos não termina nada, não efetiva nada, não inventa possíveis que façam seu corpo parar um pouco de balançar. Ele se mantém no mar, nas ondas do mar, tomado pela náusea e não vomita. No entanto, ele não é um prisioneiro do mar antes está aprisionado à passagem. A passagem tornou-se o processo, um processo pelo processo, um processo que é a parada do processo. Por isso ele viaja, viaja, viaja e não vai a parte alguma, não sai de si. Seu sofrimento se torna um colapso, um continuum infinito que o impede de criar outros mares, de criar outras terras.

Seu corpo se impermeabiliza aos ventos que sopram, como se estivesse fechado e, ao mesmo tempo, é um corpo hiper permeável, em carne viva, totalmente exposto a tudo. Não há nesse momento da existência de Nikos molas de amortecimento. Talvez fosse preciso fazer silêncio, esquecer. "O homem em quem não funciona este aparelho amortecedor [do esquecimento] é um verdadeiro dispéptico, nunca sai de nada [...]". (NIETZSCHE, 1992, p. $45-46)^{16}$.

16 "O esquecimento [...] é um poder ativo, uma faculdade moderadora, à qual devemos o fato de que tudo quanto nos acontece na vida, tudo quanto absorvemos, se apresenta à nossa consciência durante o estado da 'digestão', do mesmo modo que o multíplice processo da assimilação corporal tão pouco fatiga a consciência. Fechar de quando em quando
Ele vive toda a intensidade de um limiar, não cabe mais no que era e não consegue criar novos contornos. Toda sua existência está exposta, os problemas emergiram, as soluções se insinuam. Entretanto, é preciso desejar os problemas, ou melhor, desfazer-se dos falsos problemas. Mudar as perguntas, inventar soluções, experimentar outros olhares e outros dizeres. Ter a sensação de uma outra textura, possibilitar a pele ser percorrida por um frio e um calor estranho, desconhecido, incerto, suave e violento, assustador e calmo.

Nikos precisa avaliar, ora se abrir e ora se preservar, selecionar os momentos, fazer funcionar uma espécie de válvula, estaria aí sua potência. No entanto, ele se fecha às conexões e permanece deitado em sua cama. Ele está exposto a sua memória, rastejando em desespero. Seu corpo é uma grande ferida e a vida Ihe é insuportável. Um barco sem rumo vulnerável ao mar revolto.

\section{Um Profundo Mar Azul}

Do convés Nikos olha as cidades através de um binóculo. Entre seu olhar e as cidades, a miséria mostra a proximidade de sua face. Ancorados ao redor estão muitos barcos repletos de pessoas famintas que trocam trabalho por comida ou por qualquer dinheiro. É de lá que vem Li, uma menina de dez anos que carrega sempre seu irmão nas costas. Li é a vida feita criança, miséria, medo e confiança, cuidado e abandono. Ela nasceu numa sampana, vive no mar, mas sabe a terra.

Os tripulantes vão fazer tatuagens e Nikos os acompanha. Enquanto o capitão percorre os modelos expostos, um marujo vai recebendo os contornos das asas de um pássaro em suas costas e Nikos permanece sentado, fumando com um copo na mão. Ao fundo está o som do bisturi, a pele sendo rasgada, o corante penetrando-a. Esse som vai transtornando Nikos. É a dor encravada na pele, é a pele totalmente aberta à dor, são seus sulcos

as portas e janelas da consciência, permanecer insensível às ruidosas lutas do mundo subterrâneo dos nossos órgãos: fazer silêncio e tábua rasa da nossa consciência, a fim de que aí haja lugar para as funções mais nobres para governar, para rever, para pressentir [...] O homem em quem não funciona este aparelho amortecedor é um verdadeiro dispéptico, nunca sai de nada [...]" (NIETZSCHE, 1992, p. 45-46). 
se espalhando e tingindo seus contornos.

Aquela dor é grande demais, é intensa demais, é forte demais. Um desespero o invade, um limiar se rompe. Ele despedaça o copo na palma da mão e os cacos rasgam sua pele. A linha do destino se desfaz, se abre, se refaz. A vida lhe escorre entre os dedos na cor de sangue. Ele foge para o mar, para o barco, para o quarto. Deixa a água escorrer em sua mão e vai recolhendo os cacos que ficaram encravados. Eu ia esperar você voltar. Talvez seja meio repentino... mas estou esperando um filho. Seu filho. Estou assustada. Preciso de notícias suas.

Mas essas palavras, essa voz, essa dor, são apenas supostamente passadas. A realidade que portam não possui um equivalente nem no presente atual e nem no antigo presente. Elas o fazem mergulhar em outro tempo, tiram do lugar o passado e o presente e os defrontam com a imprevisibilidade do futuro. O passado não coincide com perdido, o presente não coincide com cansaço e o futuro não coincide com sem saída. Os sentidos formatados tornam-se disformes. As verdades mostram-se mentiras. As ilusões deixam escorrer suas certezas por entre o efêmero que as constitui.

Sua pele se rasgou e fez o tempo jorrar. Um tempo agora dilatado e redescoberto no próprio seio de um tempo perdido. O passado tornouse nuvem virtual ${ }^{17}$ do presente. Um passado puro que não se reduz a nenhum presente que passou, um passado que faz passar todos os presentes, uma memória pura. Nikos é lançado no ser em si do passado, em uma vertigem de incertezas que desloca o passado e o presente. Um estado impreciso, obscuro, onde os antigos sentidos não fazem mais sentido. Nem Nikos, nem seu passado, nem seu presente ou seu futuro serão mais os mesmos.

A questão não está no que fez ou deixou de fazer antes no que faz, no que está deixando de fazer. Seu presente se defronta com um duplo que o bifurca, o estilhaça, o multiplica,

170 ser e si do passado, que Bergson denominava virtual, é o que a memória involuntária toca através de um volume de duração que entrelaça as sensações do passado e as sensações do presente, possibilitando que outras sensações sejam criadas. Entre o passado que foi e o presente que é, surge um passado puro que não é nem o que foi e nem o que é, mas que passa a estar entre o presente e o passado fazendo com que estes não sejam mais os mesmos, é a diferença interiorizada, segundo Proust, experimentada, tornada imanente. É a imagem da eternidade, o puro infinitivo do tempo, um tempo vazio, anônimo, impessoal, desértico e neutro que nos sacode e nos atordoa e nos lança na invenção de outras formas de vida. (DELEUZE, 1987). o embaralha. O que Nikos está ajudando a fazer dele mesmo? Que outra vida é possível? O passado que o ronda não reclama uma redenção antes o força a uma afirmação. O tempo se rasgou em ilimitados possíveis. É preciso uma redistribuição dos afetos para dar contorno a esse acontecimento. Nikos precisa se esquecer para possibilitar outras vidas.

Mas ele ainda não consegue compreender essa vidência, experimentar essa outra dor e, também, essa outra alegria. As palavras se quebraram e há tudo por dizer. O amor se partiu e há tudo por amar. A memória se desfez e há tudo por lembrar e tudo a esquecer. 0 eu se dissipou e há múltiplos modos de existência. A vida saiu dos trilhos e há ilimitados caminhos a serem percorridos.

Ele responde: Não sei..., Talvez... No entanto, pode não ser expressão de um fechamento, de um adiamento de qualquer afirmação. Talvez, seja a própria incerteza dilacerando-o, os próprios sentidos se formando, uma abertura. Uma potência de possível que está ainda inventando suas possibilidades. Um informe que ainda vê talhar-se suas formas. Um mar revolto que aprende a força e a suavidade das ondas que tocam a areia.

Nikos se deita novamente. Li quer saber: Quando vai partir? O navio fora vendido e eles têm apenas dois dias. O tempo de espera anuncia seu fim. O capitão Ihe convida a embarcar em outro navio. Ele não sabe o que irá fazer. O mar não me atrai mais. Quando piso em terra, ela fica se mexendo... Ele não está em terra e nem no mar. O mar não o atrai mais e a terra treme. O mar é revolto e a terra movediça. Em meio ao mar e a terra. Ele não consegue experimentar a calmaria do mar e a firmeza da terra. É tarde demais. Ou cedo demais.

Li lhe pergunta: Qual o meu cheiro? Cheiro de camomila. Uma planta que secamos para fazer infusões. Acalma. Como o ópio? Ao contrário. Li diz que seu avô acende um cachimbo por mês para toda a família: É como fazer uma viagem... Não deve fumar muito se quiser voltar da viagem.

Nikos não suporta mais e explode em choro, seu desespero se extravasa em lágrimas. Nessa instabilidade, a memória volta. O bebê cresce em meu útero. Queria chamá-lo Nikos. Perdi a esperança. 'Eu te amo' em grego é s'agapô. O seu corpo estremece e soluça em um pranto que contém toda a dor do nasci- 
mento, de um corpo que reclama novos contornos, de uma existência em expansão que vai rasgando a pele morta ${ }^{18}$.

Nikos consegue emprego em um outro navio. Ao se despedir de Li ele diz que irá voltar para vê-la. Ela não acredita nisso. O Dragão Bondoso só vem uma vez. A maioria nunca o encontra. Eu o conheci. Amarre-o para ficar com ele, Ihe sugere Nikos. Se fizer dele um escravo, ele não servirá mais.

\section{Referências}

BALEIRO, Z. Flor da Pele. In: BALEIRO, Z. Por Onde Andará Stephen Fry? Direção: Marco Mazzola. São Paulo: MZA Music, [199-]. Distribuição Polygram. 1 compact disk, faixa 5, 3min 19s.

BLANCHOT, M. A Conversa Infinita. Tradução Aurélio Guerra Neto. São Paulo: Escuta, 2001.

CALVINO, Í. As Cidades Invisíveis. Tradução: Diogo Mainardi. São Paulo: Companhia das Letras, 1999.

DELEUZE, G. Espinoza e os Signos. Tradução: Abílio Ferreira. Porto: RÉS-Ed., [19--].

DELEUZE, G. Lógica do Sentido. Tradução: Luiz Roberto Salinas Fortes. São Paulo: Perspectiva, 1974.

DELEUZE, G. Nietzsche e a Filosofia. Tradução: Edmundo F. Dias, Ruth J. Dias. Rio de Janeiro: Ed. Rio, 1976.

DELEUZE, G. Apresentação de Sacher-Masoch. Tradução: Jorge Bastos. Rio de Janeiro: Taurus Ed., 1983.

DELEUZE, G. Proust e os Signos. Tradução: Antonio Carlos Piquet, Roberto Machado. Rio de Janeiro: Forense-Universitária, 1987.

DELEUZE, G. Diferença e Repetição. Tradução: Luiz B.L. Orlandi, Roberto Machado. Rio de Janeiro: Graal, 1988.

DELEUZE, G. Cinema II: a imagem-tempo. Tradução: Eloísa de Araújo Ribeiro. São Paulo: Brasiliense, 1990.

DELEUZE, G. O que é a Filosofia? Tradução: Bento Prado Júnior, Alberto Alonso Muñoz. Rio de Janeiro: Ed. 34, 1992a.

DELEUZE, G. L'Epuisé. Paris: Minuit, 1992b.

DELEUZE, G. Mil Platôs: capitalismo e esquizofrenia. Tradução: Aurélio Guerra Neto, Ana Lúcia de Oliveira, Lúcia Claudia Leão, Suely Rolnik. Rio de Janeiro: Ed. 34, 1996a. V. 3.

DELEUZE, G. Desejo e Prazer: carta de Deleuze a Foucault. Cadernos de Subjetividade, São Paulo, n. esp., p. 13-25, jun. 1996b.

DELEUZE, G. Mil Platôs: capitalismo e esquizofrenia. Tradução: Peter Pál Pelbart, Janice Caiafa. São Paulo: Ed. 34, 1997b. V. 5.

DELEUZE, G. Curso de los Martes, Spinoza. Tradução: Ernesto Hernández. Santiago de Cali: [s.n.], 1997a. Disponível em: <www.imaginet.fr/Deleuze>. Acesso em: 01 set. 1998.

DELEUZE, G. Bergsonismo. Tradução: Luiz B.L. Orlandi. São Paulo: Ed. 34, 1999.

DELEUZE, G.; GUATTARI, F. O Anti-Édipo: capitalismo e esquizofrenia. Tradução: Joana Morais Varela, Manoel Maria Carrilho. Lisboa: Assírio \& Alvim, 1972.

ENTRE o Inferno e o Profundo Mar Azul. Direção: Marion Hänsel. Produção: Grupo Mundial Filmes e Seawell Filmes. Roteiro: ?. Intérpretes: Stephen Rea; Ling Chu et al. [França; Inglaterra; Bélgica]: Grupo Mundial Filmes, [1995?]. 1 filme (92min), son., color.

18 ''Ovo tântrico', grande feto, coisa viva se mexendo, ele circula crescendo na barriga-terra, sentindo o calor da luz, alimentando-se da claridade-nutrição que habita seu próprio desejo. Claridade que é matéria e energia. Que não se veja, todavia, nesse ovo ou nesse feto, uma regressão [...]" (LINS, 1999, p. 65). 
ESPINOSA, B. de. Ética. Tradução: Joaquim de Carvalho, Joaquim F. Gomes, António Simões. Lisboa: Relógio D’Água Ed., 1992.

FERREIRA, A.B. de H. Dicionário Eletrônico Aurélio Séc. XXI: com corretor ortográfico. Rio de Janeiro: Nova Fronteira, [2001]. 1 CD-ROM.

FOUCAULT, M. O Pensamento do Exterior. Tradução: Nurimar Falci. São Paulo: Ed. Princípio, 1990.

LEFEBVRE, H. A Vida Cotidiana no Mundo Moderno. Tradução: Alcides João de Barro. São Paulo: Ática, 1991.

LINS, D. Antonin Artaud: o artesão do corpo sem órgãos. Rio de Janeiro: Relume Dumará, 1999.

LISPECTOR, C. Um Sopro de Vida: pulsações. Rio de Janeiro: Ed. Rocco, 1978.

MACHADO, L.D. À Flor da Pele. Orientação: Luiz Benedicto Lacerda Orlandi. 2002. Tese (Doutorado) - Programa de Pós-Graduação em Psicologia Clínica, Pontifícia Universidade Católica de São Paulo, 2002, São Paulo, BR-SP.

NIETZSCHE, F. Assim Falava Zaratustra. Tradução: Alfredo Margarido. Portugal: Guimarães Ed., 1985.

NIETZSCHE, F. A Genealogia da Moral. Tradução: Carlos José de Meneses. Lisboa: Guimarães Ed., 1992.

ORLANDI, L.B.L. Anotações de Aulas ministradas no Programa de Pós-Graduação em Psicologia Clínica - Núcleo de Subjetividade, PUC-SP, abril de 2000.

ORLANDI, L.B.L. Que Estamos Ajudando a Fazer de Nós Mesmos? In: RAGO, M.; ORLANDI, L.B.; VEIGANETO, A. (Org.). Imagens de Foucault e Deleuze: ressonâncias nietzschianas. Rio de Janeiro: DP\&A, 2002. P. 217-238.

PELBART, P.P. O Tempo não Reconciliado. São Paulo: Perspectiva/FAPESP, 1998.

PROUST, F. La ligne de résistance. In: DELEUZE, G. Immanence et vie. Paris: Collège International Philosophie, PUF, 1988. P. 35-48.

ROLNIK, S. O Mal-Estar na Diferença. Anuário Brasileiro de Psicanálise, Rio de Janeiro, n. 3, p. 97-103, 1995.

ZOURABICHVILI, F. Deleuze e o Possível: sobre o involuntarismo na política. In: ALLIEZ, E. (Org.). Gilles Deleuze: uma vida filosófica. Tradução: Ana Lúcia de Oliveira. São Paulo: Ed. 34, 2000.

Recebido em março de 2010.

Aprovado para publicação setembro de 2010.

\section{Leila Domingues Machado}

Doutora em Psicologia Clínica na Pontifícia Universidade Católica-SP e Pós-Doutora em Psicologia Social na Universidade Estadual do Rio de Janeiro. Professora do Departamento de Psicologia e do Programa de Pós-Graduação em Psicologia Institucional da Universidade Federal do Espírito Santo - UFES, Vitória-ES/Brasil.

Email: leiladomingues@uol.com.br 